University of Nebraska - Lincoln

DigitalCommons@University of Nebraska - Lincoln

USDA National Wildlife Research Center - Staff

Publications

U.S. Department of Agriculture: Animal and Plant Health Inspection Service

2008

\title{
Passive Immunity to West Nile Virus Provides Limited Protection in a Common Passerine Species
}

Nicole M. Nemeth

Colorado State University, nnemeth@colostate.edu

Paul T. Oesterle

National Wildlife Research Center

Richard A. Bowen

National Wildlife Research Center

Follow this and additional works at: https://digitalcommons.unl.edu/icwdm_usdanwrc

Part of the Environmental Sciences Commons

Nemeth, Nicole M.; Oesterle, Paul T.; and Bowen, Richard A., "Passive Immunity to West Nile Virus Provides Limited Protection in a Common Passerine Species" (2008). USDA National Wildlife Research Center - Staff Publications. 1050.

https://digitalcommons.unl.edu/icwdm_usdanwrc/1050

This Article is brought to you for free and open access by the U.S. Department of Agriculture: Animal and Plant Health Inspection Service at DigitalCommons@University of Nebraska - Lincoln. It has been accepted for inclusion in USDA National Wildlife Research Center - Staff Publications by an authorized administrator of DigitalCommons@University of Nebraska - Lincoln. 


\title{
Passive Immunity to West Nile Virus Provides Limited Protection in a Common Passerine Species
}

\author{
Nicole M. Nemeth,* Paul T. Oesterle, and Richard A. Bowen \\ Department of Microbiology, Immunology and Pathology, Department of Fish, Wildlife and Conservation, and Department of \\ Biomedical Sciences, Colorado State University, Fort Collins, Colorado; National Wildlife Research Center, USDA/APHIS/WS, \\ Fort Collins, Colorado
}

\begin{abstract}
Passerine birds have played an important role in the establishment, maintenance, and spread of West Nile virus (WNV) in North America, and some are susceptible to WNV-associated mortality. Characterization of passive transfer of anti-WNV antibodies in passerines is important to understanding transmission and demographic effects of WNV on wild birds. We showed passively acquired maternal antibodies to WNV in the house sparrow (Passer domesticus). Although all seropositive females $(N=18)$ produced antibody-positive egg yolks, only $20 \%$ of seropositive mothers $(3 / 15)$ produced seropositive chicks. The estimated average half-life of maternal antibodies in chick sera was 3 days, and no antibodies were detected after 9 days post-hatch (DPH). Maternal antibodies failed to provide protection against viremia in chicks at 21-25 DPH. Although the observed duration of persistence of passively inherited anti-WNV antibodies in house sparrows differs from some non-passerine birds, it remains unknown whether similar patterns occur in other passerines.
\end{abstract}

\section{INTRODUCTION}

Hatchling birds are exposed to an array of pathogens, thereby necessitating temporary immunologic assistance. ${ }^{1,2}$ Maternally derived antibodies circulate within blood of newly hatched chicks and provide this temporary protection while the immune system matures. ${ }^{2}$ Passive transfer of immunity to West Nile virus (WNV; family Flaviviridae, genus Flavivirus) has been documented in captive rock doves (Columba livia), eastern screech owls (Megascops asio), and domestic chickens (Gallus gallus domesticus). ${ }^{3-5}$ In addition, young birds of some species are more susceptible to higher West Nile viremia levels and associated morbidity and mortality than older individuals, ${ }^{5,6}$ and nestling birds may be susceptible to higher mosquito feeding rates because of their lack of defensive behavior. ${ }^{7,8}$ Therefore, early-age immune protection against WNV infection should mitigate transmission and disease in birds. $^{5}$

Passive transfer of anti-WNV antibodies has yet to be documented in Passeriformes, the largest and most diverse order of birds. Passerines have been implicated as reservoir hosts of WNV and were likely important in its spread across North America. ${ }^{9-11}$ The house sparrow (Passer domesticus) is of interest because it is a highly competent amplifying host of WNV, is abundant within many habitat types, and has a broad geographic range that includes much of North America. ${ }^{10,12,13}$ The extent of passive transfer of antibodies to WNV in passerines has important consequences on WNV transmission in nature, as well as the health of free-ranging birds. ${ }^{5}$ There may be differences in patterns of passive transfer of anti-WNV antibodies among avian individuals and species, and these differences could be associated with varying immune investment in offspring because of physiological trade-offs associated with life history traits of both adults and young. $1,14,15$

The hypothesis of this study was that transovarial transfer

\footnotetext{
* Address correspondence to Nicole M. Nemeth, Department of Microbiology, Immunology and Pathology, 3801 West Rampart Road, Foothills Campus, Colorado State University, Fort Collins, CO 80523-1683. E-mail: nnemeth@colostate.edu
}

of antibodies to WNV occurs in the house sparrow, and maternal antibodies are detectable in both eggs and chicks of seropositive mothers. In addition, we predicted that, as in chickens, maternal antibodies in house sparrow chicks would be protective against viremia and clinical disease. ${ }^{5}$ The objectives of this study were to 1) show maternal antibodies to WNV in eggs and chicks derived from known seropositive female sparrows; 2) document the decay of maternal antibodies in chicks over time; and 3) evaluate viremia, oral shedding, and viral titers in tissues after WNV inoculation of chicks from both seropositive and seronegative mothers.

\section{MATERIALS AND METHODS}

Capture, husbandry, and inoculation of adult sparrows. A captive flock of house sparrows, captured by mist nets in Weld County, Colorado, was established in early 2005. The maintenance and care of the sparrow colony was in compliance with the National Institutes of Health guidelines for the humane use of laboratory animals, and the research was conducted under Institutional Animal Care and Use approval. Birds were housed free-flight in an indoor, mosquito-proof aviary (3.24 m width $\times 2.57 \mathrm{~m}$ height $\times 12.12 \mathrm{~m}$ length) and provided with tree branches (with leaves and buds depending on season) and trunks and sand baths. Environmental conditions within the aviary were maintained at $\sim 10-20^{\circ} \mathrm{C}$ and $15-$ $25 \%$ humidity, with a photoperiod determined by natural sunlight.

Sparrow diet consisted of a mix of millet, milo, cracked corn, cracked sunflower seed, and oats (in equal parts), supplemented one to two times a week with live mealworms. Cuttlefish bone was provided as an additional source of calcium and to prevent beak and nail overgrowth. During the breeding season, adult sparrows were also provided with cooked egg, mealworm pupae, waxworms, soaked kitten chow, Family Farm Egg Maker 16 crumbles, and ground oyster shell.

West Nile virus serostatus of all individuals was determined on arrival, and a portion of seronegative sparrows was experimentally inoculated by subcutaneous injection with $\sim 1,000$ 2,000 plaque forming units (PFU) of WNV strain NY99-4132, which was originally isolated from an infected crow and was 
passaged once in Vero cells, once in C6/36 mosquito cells, and once in baby hamster kidney-21 cells.

During the 2007 breeding season (April-August), 25 months after WNV inoculation, some sparrows began nest building using provided materials (grass, cotton, and shredded paper) and structures (1-gal plastic cartons with cut holes for nest openings). At this time, the flock consisted of 30 adult females ( $25 \mathrm{WNV}$ seropositive and 5 seronegative) and 25 males (20 WNV seropositive and 5 seronegative).

Nest observations. Observations of breeding behavior, including identification of individuals that were mating, nest building, incubating eggs, and brooding and feeding chicks, were performed from within a blind inside the aviary. All observations were confirmed through video recordings prepared daily throughout the breeding season. The identities of the male and female attending a given nest were reassessed after fledging of each clutch of chicks to detect any change in parents. Females incubating, brooding and feeding young were assumed to be the producers of the eggs in their respective nests. Males observed to have copulated with the attending female, and also incubating, brooding, and feeding young were identified; however, extra-pair copulations could not be ruled out, so definitive identities of fathers remained unknown.

Sample collection and preparation for assessment of maternal antibodies. Sparrow adults were bled just before initiation of the breeding season (April 1, 2007) and after its conclusion (October 1, 2007) to determine anti-WNV antibody titers.

From late April through July, nests were checked every other day; for the remainder of the nesting season, nests were checked daily to determine numbers of eggs and chicks present. For the time period when nests were checked every other day, chicks' hatch date was considered the earlier of the two possible dates.

Early in the breeding season (May-June), eggs that were laid on the ground or ejected from the nest were opportunistically collected if deemed fresh by the appearance of the yolk. Later in the season (July-August), one to three eggs were collected directly from active nests. Ova were collected at necropsy from several females that died with broken eggs and/or developing ova within the reproductive tract. In addition, yolk sacs (residual yolk supply contained within chicks' abdomen at the time of hatch) and blood samples were collected post-mortem when possible from chicks $\leq 1$ day posthatch (DPH) that were found dead or were injured and humanely killed. In some cases, the mothers of recovered eggs or chicks were unknown.

Ova, yolks, and yolk sacs were aseptically collected into cryovials, diluted 1:2.5 or 1:5 in BA1 medium (M199-Hank's salts, $1 \%$ bovine serum albumin, $350 \mathrm{mg} / \mathrm{L}$ sodium bicarbonate, $100 \mathrm{units} / \mathrm{mL}$ penicillin, $100 \mu \mathrm{g} / \mathrm{mL}$ streptomycin, and 2.5 $\mu \mathrm{g} / \mathrm{mL}$ amphotericin $\mathrm{B}$ in $0.05 \mathrm{~mol} / \mathrm{L}$ Tris, $\mathrm{pH} 7.6$ ), vortexed until homogenized ( $\sim-10$ seconds), and clarified by centrifugation. Supernatants were stored at $-20^{\circ} \mathrm{C}$ until testing.

Some sparrow chicks were bled serially over time, beginning between 1 and 9 DPH and then sampled every 3-5 days until fledging or soon thereafter (up to $26 \mathrm{DPH}$ ). Just before collection of blood samples, nestlings were weighed with a Pesola spring balance (Pesola AG, Baar, Switzerland) of accuracy to $1 \mathrm{~g}$. Blood was collected by jugular venipuncture ( $\leq 1 \%$ of body weight), placed into serum separator tubes, maintained at room temperature for $\sim 30$ minutes, centrifuged for separation of serum, and stored at $-20^{\circ} \mathrm{C}$ until testing.

Husbandry, inoculation, and sample collection from chicks. Chicks of two different age groups were separated from the flock for experimental inoculation with WNV. Environmental conditions for chicks were maintained at $24-27^{\circ} \mathrm{C}$ and 40 $50 \%$ humidity. Chicks were either placed into an artificial nest cavity or a cage, depending on age. The first group of chicks was removed from the nest between 4 and 5 DPH and consisted of one chick from a seronegative female and three chicks from two different seropositive females. These chicks were hand-fed $\sim 65 \%$ body weight daily (divided into feedings every 1-1.5 hours), consisting of mealworms, mealworm pupae, cooked egg, fruit cocktail, waxworms, and cricket abdomens. The second group of chicks was removed from the aviary between 19 and $23 \mathrm{DPH}$ and consisted of two siblings derived from a seronegative female and four chicks from three different seropositive females. This group was provided water, seed mix (millet, milo, cracked corn, cracked sunflower seed, and oats), cooked egg, soaked kitten chow, mealworm pupae, chicken crumble feed, and waxworms ad libitum.

Both cohorts of chicks were challenged with 3,000-5,000 PFU WNV by subcutaneous injection: the younger cohort at 7-8 DPH and the older at 21-25 DPH. Blood samples $(0.1 \mathrm{~mL})$ were collected from the jugular vein of chicks (all weighing $>20 \mathrm{~g}$ ) from 1 to 6 days post-infection (DPI), and sera were recovered after centrifugation. Oropharyngeal cavities were sampled with cotton-tipped swabs from 1 to 7 DPI (or until death/euthanasia), after which the swabs were placed into $1 \mathrm{~mL}$ BA1. Chicks showing signs of morbidity (lethargy, fluffed feathers, and/or poor body condition) were killed by sodium pentobarbital overdose. Survivors were bled and killed on 10 DPI. After death or euthanasia, chicks were necropsied, and the following samples collected for virus titration: oral and cloacal swab, heart, liver, spleen, kidney, small intestine, skeletal muscle, and cerebrum. Sera, swabs, and tissue homogenates $(\sim 10 \%$ tissue suspension in $\mathrm{BA} 1$, as previously described $)^{16}$ were stored at $-80^{\circ} \mathrm{C}$ until testing.

Laboratory testing. Neutralizing antibody titers of yolk and yolk sac supernatant and sera were determined by plaque reduction neutralization test (PRNT) on Vero cell monolayers in six-well plates as previously described. ${ }^{17}$ The same WNV strain used for inoculation of adults and chicks was used for PRNT. Serum samples that showed $\geq 80 \%$ neutralization at a 1:10 dilution were considered positive for antiWNV antibodies, and these samples were serially diluted (2fold) to determine reciprocal endpoint $80 \%$ neutralization $\left(\mathrm{PRNT}_{80}\right)$ titers.

Viral titers of sera, oral swabs, and tissue homogenates of WNV-inoculated chicks were determined by Vero cell plaque assay as previously described. ${ }^{18}$ Minimum levels of WNV detection were $10^{1.7} \mathrm{PFU} / \mathrm{mL}$ for sera, $10^{0.7} \mathrm{PFU} / \mathrm{swab}$, and $10^{1.7}$ $\mathrm{PFU} / \mathrm{g}$ for tissues.

Statistics and calculations. Chicks included in the calculation of estimated average half-life of passive antibodies $(N=$ 10) had at least two serum samples collected over time, with the first showing between $70 \%$ and $99 \%$ neutralization of WNV at a 1:10 dilution and $>50 \%$ neutralization by a subsequent serum sample. Serial samples were collected from 2 to 12 days apart (with chick ages on collection ranging from 1 to $16 \mathrm{DPH}$ ). To calculate half-life, the percent neutralization 
at a 1:10 dilution (50-99\%) was rescaled to a value between 0 and $\approx 1.0$ (the rescaled value is referred to as "neutralizing activity" or NtA) by converting the percentage to a proportion, subtracting 0.50 from the proportion, and multiplying the result by 2 (e.g., $75 \%$ neutralization would be adjusted to $[0.75-0.50] \times 2=0.50 \mathrm{NtA})$. This adjustment considered $50 \%$ neutralization as having zero NtA, and $99 \%$ neutralization as having virtually complete NtA. Samples with $100 \%$ neutralization were excluded because an accurate relative quantification of this level cannot be achieved. An estimate of half-life was calculated using the following equation, adapted from an equation for radioactive decay. ${ }^{19}$

$$
\text { half }- \text { life }=\frac{(\text { days elapsed }) \times \log _{10} 2}{\log _{10}(\text { initial NtA } / \text { final NtA })}
$$

Reservoir competence indices (RCIs) were calculated for sparrow nestlings and juveniles inoculated with WNV and were based on susceptibility (s), infectiousness (i), and duration of infectiousness (d), so that RCI $=\mathrm{s} \times \mathrm{i} \times \mathrm{d} .{ }^{12,20,21}$ Susceptibility for all sparrows was 1.0 , because $100 \%$ of chicks were considered susceptible to WNV infection. ${ }^{20}$ Percent infectiousness was calculated as: ${ }^{21}$

$$
\text { \% Infectiousness }=0.1349 \times \log _{10}(\text { viremia })-0.6235
$$

The threshold for zero infectiousness was $10^{4.62} \mathrm{PFU} / \mathrm{mL}$ (based on data from Culex pipiens), and when an individual's daily viremia value was below this level, infectiousness was considered zero for that day. ${ }^{21}$ Duration of infectiousness was the number of days that viremia levels were above the threshold of infectiousness. These values were averaged for each individual to calculate mean values for the following experimentally inoculated groups: younger cohort (8-9 DPH) with seropositive mothers, younger cohort with seronegative mothers, older cohort (21-25 DPH) with seropositive mothers, and older cohort with seronegative mothers.

SAS/STAT MULTTEST software, version 9.1, (SAS Institute, Cary, NC) was used to perform a paired $t$ test to compare mean peak viremia titers for chicks from seropositive versus seronegative mothers in the older cohort using $\alpha=0.05$.

The MIXED procedure with repeated measures was used for data analysis and Akaike's information criteria (AIC) were used for model selection ${ }^{22}$ to test which sets of factors best predicted protection by mothers' WNV immunity status in the older cohort of chicks. Five models were used for the analysis of the challenge experiment of the older cohort. Model 1 (intercept only) represented a scenario in which viremia profiles were independent of all other parameters included within the model set; Model 2 examined the effect of DPI on chicks' viremia profiles; Model 3 indicated the effect of mothers' serostatus on chicks' viremia profiles; Model 4 evaluated the additive effects of DPI and mothers' serostatus; and Model 5 was fully interactive for DPI and mothers' serostatus. Individual AIC weights were calculated for each model.

Statistical analyses were not performed for the younger cohort of chicks because of the limited sample size.

\section{RESULTS}

Antibody titers of breeding females. Before experimental inoculation, all adult sparrows were negative for anti-WNV

antibodies. Of the 15 seropositive sparrow females that produced chicks, PRNT $_{80}$ antibody titers ranged from 20 to 1,280. Titers were typically the same or declined 2-fold from April 1, 2007 to October 1, 2007. However, in two females, antibody titers dropped 4-fold during this time period (Table 1).

Maternal antibodies in ova, yolks, and yolk sacs. Ova $(N=5)$ were removed from two breeding females that died. The females had serum PRNT $_{80}$ titers of 160 and 640 and those of the yolk within their ova had $\mathrm{PRNT}_{80}$ titers between 80 and 160 .

All seropositive mothers (18/18) produced eggs with antiWNV antibodies, with the majority of egg yolks produced by these females having detectable antibodies to WNV (91.4\%; 32/35). Adult females with $\mathrm{PRNT}_{80}$ titers between 20 and 1,280 produced yolks with titers between $<10$ and 320 . In general, yolk antibody titers were 4 - to 8-fold lower than those of the females' serum antibody titers. Three individual females produced both antibody positive and negative yolks; $\mathrm{PRNT}_{80}$ titers of these females ranged from 20 to 80 . Sixtyfour percent $(16 / 25)$ of yolks from unidentified females had anti-WNV antibodies (PRNT ${ }_{80}$ titers of $\left.10-80\right)$. Yolks (9/9) from four seronegative females were negative for anti-WNV antibodies, having $<60 \%$ neutralization at a dilution of 1:10 (Table 1).

TABLE 1

WNV antibody titers in house sparrow mothers and their correspond-

\begin{tabular}{|c|c|c|c|c|c|c|}
\hline \multicolumn{2}{|c|}{ Adult females } & \multicolumn{2}{|c|}{ Yolks/ova* } & \multicolumn{3}{|c|}{ Chicks } \\
\hline ID & $\begin{array}{l}\mathrm{PRNT}_{80} \\
\text { range } \dagger^{-1}\end{array}$ & $\begin{array}{l}\mathrm{PRNT}_{80} \\
\text { range } \underset{+}{+}\end{array}$ & $N$ & $\begin{array}{l}\mathrm{PRNT}_{80} \\
\text { range }\end{array}$ & $N$ & $\begin{array}{l}\text { DPH\& first } \\
\text { bled }\end{array}$ \\
\hline 1 & $20-40$ & NT & - & $<10$ & 2 & $5-6$ \\
\hline 2 & $20-40$ & $<10-10$ & 2 & $<10$ & 3 & $1-6$ \\
\hline 3 & $20-40$ & $<10-40$ & 4 & $<10$ & 3 & $3-5$ \\
\hline 4 & $20-80$ & $<10-10$ & 2 & $<10$ & 3 & 1 \\
\hline 5 & 80 & NT & - & $<10$ & 3 & $2-7$ \\
\hline 6 & 80 & $20-40$ & 3 & $<10$ & 1 & 1 \\
\hline 7 & 80 & NT & - & $<10$ & 3 & 1 \\
\hline 8 & 80 & 40 & 1 & NT & - & - \\
\hline 9 & 160 & $80-160$ & 2 & NT & - & - \\
\hline 10 & 160 & 160 & 1 & NT & - & - \\
\hline 11 & 80-160 & 20 & 4 & $<10$ & 8 & $1-5$ \\
\hline 12 & 80-160 & 20 & 1 & NT & - & - \\
\hline 13 & 160 & NT & - & 10 & 4 & $4-6$ \\
\hline 14 & 160 & $40-80$ & 3 & $<10$ & 2 & $3-6$ \\
\hline 15 & 160 & 20 & 1 & $<10-10$ & 2 & $2-4$ \\
\hline 16 & $80-320$ & 20 & 2 & $<10$ & 5 & $1-5$ \\
\hline 17 & 320 & 80 & 2 & NT & - & - \\
\hline 18 & $160-320$ & $20-40$ & 3 & $<10$ & 1 & $4-5$ \\
\hline 19 & $160-320$ & 20 & 1 & NT & - & - \\
\hline 20 & $160-320$ & NT & - & $<10$ & 3 & $5-9$ \\
\hline 21 & 640 & $40-80$ & 4 & NT & - & - \\
\hline 22 & $320-640$ & $80-160$ & 2 & NT & - & - \\
\hline 23 & 1,280 & $160-320$ & 2 & $10-40$ & 7 & $1-6$ \\
\hline 24 & $<10$ & $<10$ & 1 & NT & - & - \\
\hline 25 & $<10$ & $<10$ & 5 & NT & - & - \\
\hline 26 & $<10$ & $<10$ & 2 & $<10$ & 1 & 1 \\
\hline 27 & $<10$ & NT & - & $<10$ & 4 & $1-6$ \\
\hline 28 & $<10$ & $<10$ & 1 & $<10$ & 3 & $3-7$ \\
\hline $\begin{array}{c}\dagger \\
\text { fem } \\
\text { seas } \\
\vdots \\
\text { mot } \\
\text { clute } \\
\S \\
\text { chic }\end{array}$ & $\begin{array}{l}\text { t t serum } \\
\text { les } 24 \\
\text { a, and } \\
\text { und }\end{array}$ & $\begin{array}{l}\text { seronega } \\
\text { era with } \\
\text { tibody-po } \\
\text { l) when fir }\end{array}$ & & $\begin{array}{l}\text { th no yol } \\
\text { (PRNT } \\
\text { and afte } \\
10 \text { were }\end{array}$ & & $\begin{array}{l}\text { and Female } \\
\text { es for adult } \\
77 \text { breeding } \\
\text { tive. Some } \\
\text { n the same } \\
\text { re multiple }\end{array}$ \\
\hline
\end{tabular}
ing ova, egg yolks, and/or chicks 


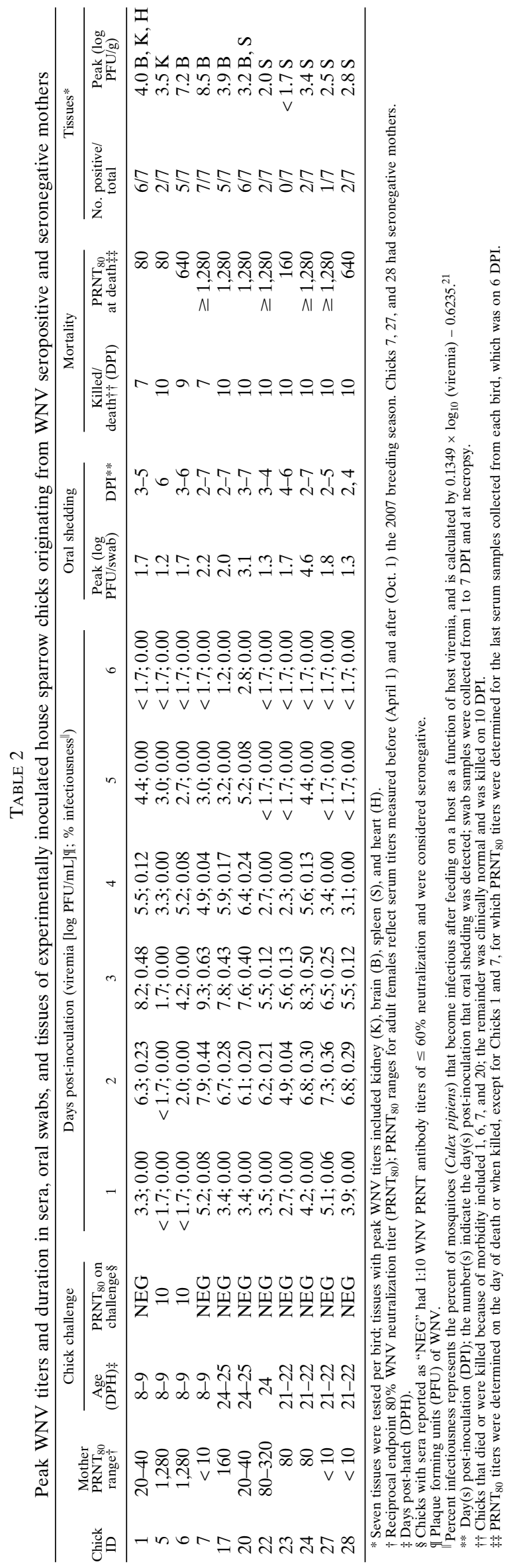

Fifteen yolk sacs were collected from neonatal chicks, seven of which were from seropositive females having $\mathrm{PRNT}_{80}$ antibody titers from 40 to 1,280 ; yolk sac $\mathrm{PRNT}_{80}$ titers were from 10 to 320 . Three of the six yolk sacs from unknown females were positive for antibodies to WNV, with PRNT $_{80}$ titers from 20 to 80 . Two yolk sacs of chicks from seronegative females were negative for anti-WNV antibodies, exhibiting $<60 \%$ neutralization at a dilution of 1:10.

Maternal antibodies in chicks. Fifty-eight chicks were bled on or before 7 DPH (20 of these were bled on 1 DPH). Fifty of these chicks were from 15 seropositive mothers, which had WNV PRNT ${ }_{80}$ titers ranging from 20 to 1,280 . Three of the 15 mothers $(20 \%)$ produced seropositive chicks, and $\mathrm{PRNT}_{80}$ titers of these mothers were 160 and 1,280. Alternatively, $24 \%(12 / 50)$ of the chicks from seropositive mothers had detectable WNV neutralizing antibodies, with PRNT $_{80}$ titers of chick sera ranging from 10 to 40 . All seven chicks from a female with a $\mathrm{PRNT}_{80}$ of 1,280 had detectable maternal antibodies; these chicks were from three separate clutches, each $\sim 1$ month apart. No chicks were positive for maternal antibodies to WNV after $9 \mathrm{DPH}$. The estimated average half-life of anti-WNV antibodies in chicks $(N=10)$ was $\sim 71.92$ hours or 3 days (range, 1.43-5.91 days). Sera from the eight chicks from seronegative mothers exhibited $<60 \%$ neutralization at a dilution of 1:10.

Challenge of chicks from seropositive and seronegative females. All 11 of the chicks challenged with WNV by subcutaneous injection developed detectable WNV viremia titers of variable duration between 1 and 6 DPI (Table 2).

Within the younger cohort (8-9 DPH), peak viremia titers were higher in the two chicks that had undetectable antibodies on inoculation (average, $10^{9.0} \mathrm{PFU} / \mathrm{mL}$ serum); one of these chicks was from a seropositive mother (Table 2). The average peak viremia of the two chicks that had detectable maternal antibodies at hatch (and also at inoculation) was $10^{4.9} \mathrm{PFU} / \mathrm{mL}$ serum, whereas viremia in all four chicks was undetectable by 6 DPI. Based on these viremia data, the mean percent infectiousness value for the younger cohort that had seropositive mothers was 0.30 versus 1.19 for the chick with a seronegative mother. Reservoir competence indices for these groups were 0.40 and 4.76 , respectively (Table 3 ). All four chicks in the younger cohort shed virus from the oral cavity. The chick from the seronegative mother had higher viral tissue loads and more virus-positive tissues than the chicks from seropositive mothers. Although several chicks in the younger cohort were euthanized because of lethargy and weight loss, it was difficult to distinguish clinical signs attributable to WNV infection versus those resulting from the stress of frequent handling for feeding. All chicks in the younger cohort seroconverted by 6-10 DPI (Table 2).

None of the seven chicks in the older cohort had detectable anti-WNV antibodies at the time of inoculation on 21-25 DPH, although five had seropositive mothers. Viremia was first detected in all chicks on 1 DPI and lasted between 4 and $\geq 6$ days (Table 2). There was no significant difference in the mean peak viremia titers of chicks from seropositive versus seronegative mothers in the older cohort $\left(10^{7.8}\right.$ PFU versus $10^{7.4} \mathrm{PFU}$, respectively; $t$ test, $P=0.27$ ). In addition, model selection based on AIC weight indicated that mothers' serostatus (Model 3) had a minimal effect on chick viremia profiles (Table 4). Based on viremia data, the mean percent infectiousness for the older cohort with seropositive mothers 
TABLE 3

Viremia parameters and RCIs for house sparrow chicks from females with and without antibodies to WNV

\begin{tabular}{lccccc}
\hline $\begin{array}{c}\text { Mother WNV } \\
\text { antibody status }\end{array}$ & $\begin{array}{c}\text { Age (DPH)* } \\
\text { at inoculation }\end{array}$ & Susceptibility & $\begin{array}{c}\text { Mean percent } \\
\text { infectiousness } \dagger\end{array}$ & $\begin{array}{c}\text { Mean } \\
\text { duration of } \\
\text { infection } \ddagger\end{array}$ & RCI§ \\
\hline Positive & $8-9$ & 1.0 & 0.30 & 1.33 & 0.40 \\
Negative & $8-9$ & 1.0 & 1.199 & 4.00 & 4.76 \\
Positive & $21-25$ & 1.0 & 0.64 & 2.80 & 1.80 \\
Negative & $21-25$ & 1.0 & 0.55 & 2.50 & 1.36 \\
\hline
\end{tabular}

* DPH (days post-hatch) when inoculated with WNV $\dagger$ Mean infectiousness is based on a viremia-infectiousness relationship for Culex pipi-

$\doteqdot$ Mean duration of infection represents the average number of days viremia titers were above the zero threshold of infection for Culex pipiens $\left(10^{4.62} \mathrm{PFU} / \mathrm{mL}\right)$.

$\S \mathrm{RCI}=$ susceptibility $\times$ mean infectiousness $\times$ duration of infectiousness (in days). ${ }^{12,20}$

q[ Percent mean infectiousness represents only one individual's viremia.

was 0.64 versus 0.55 for the chicks with seronegative mothers. Reservoir competence indices for these groups were 1.80 and 1.36, respectively (Table 3 ). Low WNV titers were detected at 10 DPI in spleen and/or kidney of chicks with seronegative mothers, whereas chicks with seropositive mothers had WNV in up to six different tissues. One chick, which was from a seropositive mother, experienced clinical signs attributed to WNV infection (older chicks were only handled for daily sample collection because they fed independently), including lethargy and weight loss first observed on 7 DPI. However, this chick continued eating and remained relatively alert and active and was killed on 10 DPI with the others. All chicks in the older cohort seroconverted by 10 DPI (Table 2).

\section{DISCUSSION}

Maternal immunoglobulin G (IgG, or IgY in birds) is passively transferred from the female's serum to embryonic circulation via the yolk while eggs are in the ovary. ${ }^{23}$ Maternal antibodies to WNV have been documented in three bird species through captive studies, including pigeons, screech owls, and chickens, with additional evidence for maternal antibodies in free-ranging hawks, owls, and various aquatic species such as herons, egrets, ibis, flamingoes, storks, gulls, terns, and pochards. ${ }^{3-5,24-26}$ More data are needed to better compare the relative abilities of a variety of avian species to produce and transfer anti-WNV antibodies to their young.

Maternal antibodies to West Nile virus have yet to be documented in a passerine species, some of which are highly susceptible to WNV infection and are probable amplifying reservoir hosts. ${ }^{12}$ The house sparrow is a common and ubiquitous passerine and is regarded as an important reservoir host of WNV, with a potential role in its spread throughout North America. ${ }^{10,11,20,27}$ House sparrow nestlings are altricial, remaining sparsely feathered for 7-10 days and relatively inactive within the nest for $\sim 14$ days, ${ }^{13}$ and are thereby vulnerable to mosquito blood feeding. Mosquitoes seem to be attracted to bird nests and may increase feeding rates on older nestlings, in part because brooding times decrease, leaving nestlings more vulnerable. ${ }^{8,28,29}$ Furthermore, numerous mosquito species in North America are ornithophilic and feed at heights that coincide with the presence of house sparrows. ${ }^{30}$ House sparrows usually nest within enclosed spaces, ${ }^{13}$ and although the effects of nest structure on mosquito feeding rates are not well known, evidence suggests that house sparrow nestlings are exposed to arboviruses. ${ }^{31}$ Passive transfer in passerines could lead to dampened WNV transmission while increasing survival rates of exposed chicks.

This study documented passive transfer of antibodies to WNV in the house sparrow; maternal antibodies were apparent in ova, egg yolks, yolk sacs, and chick sera. High proportions of ova, egg yolks, and yolk sacs derived from WNVseropositive sparrow females had detectable antibodies, whereas antibodies were present in a lower proportion of sparrow chick sera post-hatch. Chicks that did have detectable maternal antibodies also had mothers with relatively high anti-WNV antibody titers, and only $20 \%$ of seropositive mothers produced chicks with detectable antibodies. In contrast, all seropositive mothers produced eggs with detectable antibodies within the yolk (Table 1). Detectable maternal antibodies to WNV were relatively short-lived in sparrows $(\leq 9 \mathrm{DPH})$ compared with other bird species in which maternal antibodies were detected for up to $\sim 28 \mathrm{DPH} .{ }^{3-5}$ However, $44-50 \%$ of screech owl chicks from WNV seropositive mothers lacked detectable antibodies between 4 and 16 DPH. ${ }^{4}$ Maternal antibodies to avian polyomavirus (APV) and Newcastle disease virus (NDV) have also been reported as short-lived, with antibodies observed in the majority (78$83 \%$ ) of budgerigar (Melopsittacus undulatus) yolks derived from seropositive mothers $(N=14$ for APV, $N=12$ for NDV) but not in chick sera on 5 DPH $(N=35$ for APV, $N=13$ for NDV). ${ }^{32}$

Numerous factors may affect the transovarial transfer of antibodies from mother to offspring. Differences within and across species may be based on variation in evolutionary pressures that in turn affect life history traits, and vice versa. ${ }^{1,33}$ Animals must balance the costs (e.g., energetic, nutritional, developmental) and benefits (e.g., protection) of an immune response, a process driven by selective pressures from pathogens and life history traits of the host. ${ }^{34}$ Differences among individual mothers (e.g., genetics, age, hormone levels, stress, mate choice, stage in ovulation), as well as environmental factors (e.g., protein availability, time in season), also likely affect passive transfer. ${ }^{2,35}$ The persistence of maternal antibodies in chick circulation is also a function of the chicks' body size on hatch and developmental and metabolic rates; maternal antibodies wane from circulation when the chick begins to produce its own antibodies. ${ }^{35,36}$

Catabolism of maternal antibodies begins once the antibodies reach the chick's circulation. High rates of metabolism in birds may contribute to the rapid decay of serum antibodies, ${ }^{37}$ whereas high growth rates of house sparrow nestlings ${ }^{38}$ correspond to increases in blood volume and dilution of circulating maternal antibodies. Antibodies in chicken chick sera fell from $75-100 \%$ to $<20 \%$ of maternal levels during the first $14 \mathrm{DPH}^{36}$ In mallard (Anas platyrhynchos) ducklings, maximum serum levels of maternal IgY occurred from 3 to 7 DPH. ${ }^{39}$ The half-life of non-specific serum gamma globulin injected into chicken chicks from 1 to $7 \mathrm{DPH}$ was $\sim 72$ hours, whereas the half-life of serum albumin was 42 hours. ${ }^{37}$ In blue-and-gold macaw (Ara ararauna) chicks, antibodies against bovine serum albumin decreased exponentially, with an average serum IgY half-life of $\sim 92$ hours (3.85 days; range, 2.37-5.11 days), although antibodies were detected in the sera of some chicks until $42 \mathrm{DPH} .{ }^{40}$ The estimated average halflife of maternal antibodies to WNV in sparrow chicks in this study was $\sim 72$ hours ( 3 days), and no antibodies were detected beyond 9 DPH. This half-life is based on a limited sample of 
TABLE 4

Model set testing the relationship between factors (mothers' WNV immunity status and time post-inoculation) and chicks' viremia profiles after WNV challenge at $21-25$ days post-hatch

\begin{tabular}{|c|c|c|c|c|c|c|c|}
\hline & Model & $\mathrm{K}$ & $-2 \log L$ & AIC & AICc & $\triangle \mathrm{AICc}$ & AIC weight \\
\hline 1 & Intercept-only & 2 & 198.80 & 202.80 & 203.11 & 16.88 & 0.000 \\
\hline 2 & Time (days post-inoculation) & 3 & 179.60 & 185.60 & 186.23 & 0.00 & 0.763 \\
\hline 3 & Mothers' WNV serostatus & 3 & 198.30 & 204.30 & 204.93 & 18.70 & 0.000 \\
\hline 4 & Time + serostatus & 4 & 178.80 & 186.80 & 187.88 & 1.65 & 0.147 \\
\hline 5 & Time + serostatus $+($ Time $\times$ serostatus $)$ & 5 & 176.70 & 186.70 & 188.37 & 2.14 & 0.090 \\
\hline
\end{tabular}

$\mathrm{K}=$ number of parameters in each model; $-2 \log \mathrm{L}=2 \times \log$ likelihood; AIC $=$ Akaike's information criteria; AICc $=$ AIC with a small sample size correction factor; $\Delta$ AICc $=$ standardized AICc values (most supported model $=0$ ); Akaike weight $=$ the weight of evidence for each model.

chicks with variable blood collection time points. When the criteria and equation for half-life from this study were applied to previously published data from chickens, ${ }^{5}$ the estimated average half-life of anti-WNV-specific maternal antibodies in chicken chick sera $(N=26)$ was 20.7 days (range, 7.9-101.8 days), with evidence of circulating maternal antibodies at $42 \mathrm{DPH}$. These chicken chicks were from hens with a range of $\mathrm{PRNT}_{90}$ titers of 80-1,280.

Questions remain as to why patterns of passive transfer of maternal antibodies to WNV were different in the house sparrow versus other avian species studied thus far and whether patterns in the house sparrow are similar to those of other passerine species. The energetic costs of immune investment in offspring are high, ${ }^{14,15}$ and the relatively rapid decay of maternal antibodies in the house sparrow may reflect a low investment by the mother. Although life history traits of sparrows and many other passerines are consistent with lower immune investment in offspring (e.g., short lifespan, high reproductive output, rapid development, and small body size), ${ }^{13}$ many of these species also have a relatively short incubation phase. Shorter incubation periods often correlate with longer periods of development of acquired immunity in hatchlings, and this would suggest a higher dependence on passive transfer and innate immunity. If the protection provided by maternal antibodies is short-lived in these species, they may be more vulnerable to infection early in life before complete development of the immune system. In addition, altricial birds (e.g., passerines) have a lower yolk supply, which contains maternal IgY, compared with precocial birds (e.g., chickens), again suggesting that altricial chicks may be more vulnerable to infection during the period when maternal antibodies have waned but acquired immunity has yet to fully develop (KC Klasing and TV Leshchinsky, unpublished data). Young birds would be more susceptible to WNV infection during this period, having a potentially greater role in transmission, and possibly decreased probability of survival.

Challenge experiments of sparrow chicks in this study suggested that maternal antibodies may provide some early (8-9 DPH) protection, but apparently no protection by $21-25$ $\mathrm{DPH}$, at which time sparrow chicks have fledged from the nest $^{13}$ (Tables 2 and 4). In contrast, chicken chicks were protected by maternal antibodies to WNV for up to $42 \mathrm{DPH}$, although protection against viremia was less complete at 42 $\mathrm{DPH}$ than at $28 \mathrm{DPH}^{5}$ Maternal antibodies also protected chicken chicks from hemorrhagic enteritis-associated clinical disease for up to $56 \mathrm{DPH},{ }^{41}$ and delayed avian leukosis virus infection with reduced levels of viremia and shedding. ${ }^{42} \mathrm{Ma}-$ ternal antibodies against turkey rhinotracheitis virus did not completely protect against disease in turkey poults, although clinical signs were less severe than in poults without maternal antibodies at $1 \mathrm{DPH} .{ }^{43}$ Ludwig and others ${ }^{44}$ suggested that house sparrow nestlings with mothers immune to St. Louis encephalitis virus (SLEV) experienced "viremic enhancement" after SLEV challenge at specific time points posthatch, meaning that viremia levels were of greater duration and magnitude than in chicks from seronegative females. Although West Nile viremia profiles of sparrow chicks in this study do not seem to be consistent with viremic enhancement (Table 2), chicks in the older cohort having seropositive mothers had higher percent infectiousness and RCIs than chicks with seronegative mothers (Table 3). In contrast, chicks in the younger cohort with seropositive mothers were less likely to be infectious to $C x$. pipiens mosquitoes than the single chick from a seronegative mother, and the RCI of the latter was higher than previously calculated for all other avian species. Furthermore, only chicks in the younger cohort with seropositive mothers had a lower RCI than previously reported for house sparrows $(\mathrm{RCI} \approx 0.49-1.25),{ }^{12,20,21}$ indicating partial protection by maternal antibodies in these younger chicks. These comparisons should be considered in the context of the limited sample sizes of chicks included. Also, frequent handling of the younger cohort of chicks for handfeeding likely caused elevated stress levels that may have affected viremia profiles; effects of stress were evident through the relatively poor weight gain over time in these chicks versus those that remained with the parents (data not shown).

The ability of nestling birds to disperse and transmit pathogens may be partially dependent on the immune status of their mothers, along with the dynamics of passive transfer and protection provided by maternal antibodies. If the behavior of maternal antibodies to WNV observed in captive house sparrows in this study is similar to that of free-ranging sparrows, maternal antibodies would offer limited protection among chicks from a portion of seropositive mothers. After this short-term protection wanes, these young chicks would be competent WNV amplifying hosts and susceptible to associated morbidity and mortality. The consequences of passive transfer of anti-WNV antibodies in passerines on transmission in nature are unknown, and studies of additional passerine species would greatly contribute to understanding the complex ecological picture.

Received January 29, 2008. Accepted for publication April 20, 2008.

Acknowledgments: The authors thank Ginger Young and Stacey Elmore for invaluable help in hand-rearing sparrow chicks during the challenge portion of the study and Paul Gordy for logistical support. We also thank Nick Komar and two anonymous reviewers for contributions toward improving the manuscript.

Financial support: This research was funded by NIH Contract N01AI25489, Emerging Infectious Viral Disease Unit. 
Authors' addresses: Nicole M. Nemeth, Department of Microbiology, Immunology and Pathology, 3801 West Rampart Road, Foothills Campus, Colorado State University, Fort Collins, CO 80523-1683, Tel: 970-491-8165, Fax: 970-491-3557, E-mail: nnemeth@colostate. edu. Paul T. Oesterle, Department of Fish, Wildlife and Conservation, Colorado State University, Fort Collins, CO 80521 and National Wildlife Research Center, USDA/APHIS/WS, Fort Collins, CO 80521, Tel: 970-266-6149, Fax: 970-266-6138, E-mail: Paul.T.Oesterle@ aphis.usda.gov. Richard A. Bowen, Department of Biomedical Sciences, 3801 West Rampart Road, Foothills Campus, Colorado State University, Fort Collins, CO 80523-1683, Tel: 970-491-5768, Fax: 970491-3557, E-mail: rbowen@colostate.edu.

\section{REFERENCES}

1. Pihlaja M, Siitari H, Alatalo RV, 2006. Maternal antibodies in a wild altricial bird: effects on offspring immunity, growth and survival. $J$ Ecol 75: 1154-1164.

2. Tizard I, 2002. The avian antibody response. Semin Avian Exotic Pet Med 11: 2-14.

3. Gibbs EJ, Hoffman DM, Stark LM, Marlenee NL, Blitvich BJ, Beaty BJ, Stallknecht DE, 2005. Persistence of antibodies to West Nile virus in naturally infected rock pigeons (Columba livia). Clin Diagn Lab Immunol 12: 665-667.

4. Hahn DC, Nemeth NM, Edwards E, Bright PR, Komar N, 2006. Passive West Nile virus antibody transfer from maternal Eastern screech-owls (Megascops asio) to progeny. Avian Dis 50: 454-455.

5. Nemeth N, Bowen R, 2007. Dynamics of passive immunity to West Nile virus in domestic chickens (Gallus gallus domesticus). Am J Trop Med Hyg 76: 310-317.

6. Austin RJ, Whiting TL, Anderson RA, Drebot MA, 2004. An outbreak of West Nile virus-associated disease in domestic geese (Anser anser domesticus) upon initial introduction to a geographic region, with evidence of bird to bird transmission. Can Vet J 45: 117-123.

7. Scott TW, Edman JD, Lorenz LH, Hubbard JL, 1988. Effects of disease on vertebrates' ability to repel host-seeking mosquitoes. Scott TW, Grumstrup-Scott J, eds. The Role of VectorHost Interactions in Disease Transmission: Proceedings of a Symposium. College Park, MD: Entomological Society of America, 9-17.

8. Scott TW, Lorenz LH, Edman JD, 1990. Effects of house sparrow age and arbovirus infection on attraction of mosquitoes. $J$ Med Entomol 27: 856-863.

9. Kilpatrick AM, Daszak P, Jones MJ, Marra PP, Kramer LD, 2006. Host heterogeneity dominates West Nile virus transmission. Proc R Soc Lond B Biol Sci 273: 2327-2333.

10. Komar N, Panella NA, Burns JE, Dusza SW, Mascarenhas TM, Talbot TO, 2001. Serologic evidence for West Nile virus infection in birds in the New York City vicinity during an outbreak in 1999. Emerg Infect Dis 7: 621-625.

11. Rappole JH, Hubálek Z, 2003. Migratory birds and West Nile virus. J Appl Microbiol 94: 47S-58S.

12. Komar N, Langevin S, Hinten S, Nemeth N, Edwards E, Hettler D, Davis B, Bowen R, Bunning M, 2003. Experimental infection of North American birds with the New York 1999 strain of West Nile virus. Emerg Infect Dis 9: 311-322.

13. Lowther PE, Cink CL, 1992. House sparrow (Passer domesticus). Poole A, Stettenheim P, Gill F, eds. The Birds of North America. No. 12. Washington, DC: The Academy of Natural Sciences, The American Ornithologist's Union, 1-20.

14. Grindstaff JL, Demas GE, Ketterson ED, 2005. Diet quality affects egg size and number but does not reduce maternal antibody transmission in Japanese quail (Coturnix japonica). $J$ Ecol 74: 1051-1058.

15. Lochmiller RL, Deerenberg C, 2000. Trade-offs in evolutionary immunology: just what is the cost of immunity? Oikos 88 : 8798.

16. Nemeth NM, Hahn DC, Gould DH, Bowen RA, 2006. Experimental West Nile virus infection in eastern screech owls (Megascops asio). Avian Dis 50: 252-258.

17. Beaty BJ, Calisher CH, Shope RE, 1995. Diagnostic procedures for viral, rickettsial, and chlamydial infections. Lennette EH,
Lennette DA, Lennette ET, eds. Arboviruses. Seventh edition. Washington, DC: American Public Health Association, 189212.

18. Bunning ML, Bowen RA, Cropp CB, Sullivan KG, Davis BS, Komar N, Godsey MS, Baker D, Hettler DL, Holmes DA, Biggerstaff BJ, Mitchell CJ, 2002. Experimental infection of horses with West Nile virus. Emerg Infect Dis 8: 380-386.

19. Wang CH, Willis DL, Loveland WD, 1975. Radiotracer Methodology in the Biological, Environmental, and Physical Sciences. Englewood Cliffs, NJ: Prentice-Hall.

20. Komar N, Panella NA, Langevin SA, Brault AC, Amador M, Edwards E, Owen JC, 2005. Avian hosts for West Nile virus in St. Tammany Parish, Louisiana, 2002. Am J Trop Med Hyg 73 1031-1037.

21. Kilpatrick AM, LaDeau SL, Marra PP, 2007. Ecology of West Nile virus transmission and its impact on birds in the western hemisphere. Auk 124: 1121-1136.

22. Burnham KP, Anderson DR, 2002. Model Selection and Multimodel Inference: A Practical Information-Theoretic Approach. Second edition. New York: Springer-Verlag.

23. Rose ME, Orlans E, Buttress N, 1974. Immunoglobulin classes in the hen's egg: their segregation in yolk and white. Eur J Immunol 4: 521-523.

24. Figuerola J, Jiménez-Clavero MA, Rojo G, Gómez-Tejedor C, Soriguer R, 2007. Prevalence of West Nile virus neutralizing antibodies in colonial aquatic birds in southern Spain. Avian Pathol 36: 209-212.

25. Reisen WK, Wheeler SS, Yamamoto S, Fang Y, Garcia S, 2005. Nesting ardeid colonies are not a focus of elevated West Nile virus activity in southern California. Vector Borne Zoonotic Dis 5: 258-266.

26. Stout WE, Cassini AG, Meece JK, Papp JM, Rosenfield RN, Reed KD, 2005. Serologic evidence of West Nile virus infection in three wild raptor populations. Avian Dis 49: 371-375.

27. Langevin SA, Brault AC, Panella NA, Bowen RA, Komar N, 2005. Variation in virulence of West Nile virus strains for house sparrows (Passer domesticus). Am J Trop Med Hyg 72: 99-102.

28. Griffing SM, Kilpatrick AM, Clark L, Marra PP, 2007. Mosquito landing rates on nesting American robins (Turdus migratorius). Vector Borne Zoonotic Dis 7: 437-443.

29. Savage HM, Aggarwal D, Apperson CS, Katholi CR, Gordon E, Hassan HK, Anderson M, Charnetzky D, McMillen L, Unnasch EA, Unnasch TR, 2007. Host choice and West Nile virus infection rates in blood-fed mosquitoes, including members of the Culex pipiens complex, from Memphis and Shelby County, Tennessee, 2002-2003. Vector Borne Zoonotic Dis 7: 365-386.

30. Darbro JM, Harrington LC, 2006. Bird-baited traps for surveillance of West Nile mosquito vectors: effect of bird species, trap height, and mosquito escape rates. J Med Entomol 43: 83-92.

31. Milby MM, Reeves WC, 1990. Natural infection in vertebrate hosts other than man. Reeves WC, ed. Epidemiology and Control of Mosquito-Borne Arboviruses in California, 1943-1987. Sacramento, CA: California Mosquito and Vector Control Association, 26-65.

32. Phalen DN, Wilson VG, Graham DL, 1995. Failure of maternally derived yolk IgG to reach detectable concentrations in the sera of nestling budgerigars (Melopsittacus undulatus). Avian Dis 39: 700-708.

33. Lee KA, Martin LB II, Hasselquist D, Ricklefs RE, Wikelski M, 2006. Contrasting adaptive immune defenses and blood parasite prevalence in closely related Passer sparrows. Oecologia 150: 383-392.

34. Moret Y, 2003. Explaining variable costs of the immune response: selection for specific versus non-specific immunity and facultative life history change. Oikos 102: 213-216.

35. Grindstaff JL, Brodie ED III, Ketterson ED, 2003. Immune function across generations: integrating mechanism and evolutionary process in maternal antibody transmission. Proc $R$ Soc Lond B Biol Sci 270: 2309-2319.

36. Rose ME, Orlans E, 1981. Immunoglobulins in the egg, embryo, and young chick. Dev Comp Immunol 5: 15-20.

37. Patterson R, Youngner JS, Weigle WO, Dixon FJ, 1962. The metabolism of serum proteins in the hen and chick and secre- 
tion of serum proteins by the ovary of the hen. J Gen Physiol 45: $501-513$

38. Weaver RL, 1942. Growth and development of English sparrows. Wilson Bull 54: 183-191.

39. Liu SS, Higgins DA, 1990. Yolk-sac transmission and posthatching ontogeny of serum immunoglobulins in the duck (Anas platyrhynchos). Comp Biochem Physiol 97B: 637-644.

40. Lung NP, Thompson JP, Kollias GV, Olsen JH, Zdziarski JM, Klein PA, 1996. Maternal immunoglobulin G antibody transfer and development of immunoglobulin $\mathrm{G}$ antibody responses in blue and gold macaw (Ara ararauna) chicks. Am J Vet Res 57: 1162-1167.
41. Fadly AM, Nazerian K, 1989. Hemorrhagic enteritidis of turkeys: influence of maternal antibody and age at exposure. Avian Dis 33: 778-786.

42. Fadly AM, Smith EJ, 1991. Influence of maternal antibody on avian leukosis virus infection in white leghorn chickens harboring endogenous virus-21 (EV21). Avian Dis 35: 443-451.

43. Naylor CJ, Worthington KJ, Jones RC, 1997. Failure of maternal antibodies to protect young turkey poults against challenge with turkey rhinotracheitis virus. Avian Dis 41: 968-971.

44. Ludwig GV, Cook RS, McLean RG, Francy DB, 1986. Viremic enhancement due to transovarially acquired antibodies to St. Louis encephalitis virus in birds. J Wildl Dis 22: 326-334. 